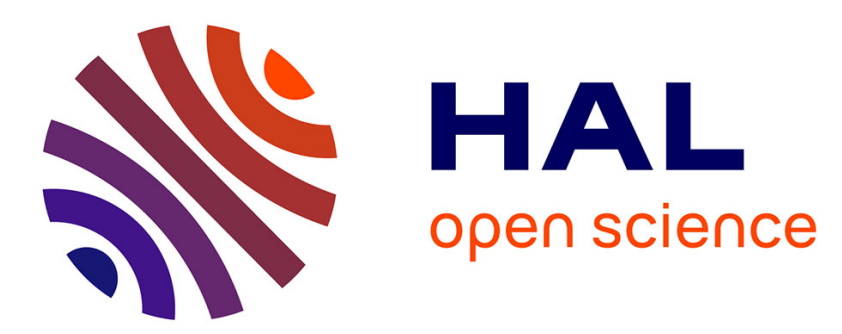

\title{
Asymmetric $\mathrm{O}-\mathrm{H}$ insertion reaction of carbenoids catalyzed by chiral bicyclo bisoxazoline copper(I) and (II) complexes
}

P. Le Maux, D. Carrié, P. Jéhan, G. Simonneaux

\section{- To cite this version:}

P. Le Maux, D. Carrié, P. Jéhan, G. Simonneaux. Asymmetric O-H insertion reaction of carbenoids catalyzed by chiral bicyclo bisoxazoline copper(I) and (II) complexes. Tetrahedron, 2016, 72 (31), pp.4671-4675. 10.1016/j.tet.2016.06.044 . hal-01367241

HAL Id: hal-01367241

https://hal-univ-rennes1.archives-ouvertes.fr/hal-01367241

Submitted on 4 Nov 2016

HAL is a multi-disciplinary open access archive for the deposit and dissemination of scientific research documents, whether they are published or not. The documents may come from teaching and research institutions in France or abroad, or from public or private research centers.
L'archive ouverte pluridisciplinaire HAL, est destinée au dépôt et à la diffusion de documents scientifiques de niveau recherche, publiés ou non, émanant des établissements d'enseignement et de recherche français ou étrangers, des laboratoires publics ou privés. 


$$
\text { R'OH + Me }
$$




\title{
Asymmetric O-H Insertion reaction of Carbenoids Catalyzed by Chiral
}

\section{Bicyclo Bisoxazoline Copper(I) and (II) Complexes.}

Paul Le Maux ${ }^{\mathrm{a}, *}$, Daniel Carrié ${ }^{\mathrm{a}}$, Philippe Jéhan ${ }^{\mathrm{b}}$, Gérard Simonneaux ${ }^{\mathrm{a}, *}$

a Institut des Sciences Chimiques de Rennes, UMR CNRS 6226, Ingénierie Chimique et Molécules pour le Vivant, Campus de Beaulieu, Université de Rennes1, 35042 Rennes Cedex, France

${ }^{b}$ CRMPO, Campus de Beaulieu, Université de Rennes1, 35042 Rennes Cedex, France

\begin{abstract}
Chiral copper(I) and (II)-bicyclobisoxazoline complexes were found to catalyse the insertion of $\alpha$-diazocarbonyl compounds into $\mathrm{O}-\mathrm{H}$ bonds of alcohols. The insertion reactions of various $\alpha$-diazopropionates proceeded with moderate yields (40-90\%) and high enantioselectivities (up to $92 \%$ and $94 \%$ with copper(I) and copper(II)-catalysts, respectively). A predominant effect on the enantiocontrol of the reaction was observed when copper(I) and (II)-catalysts

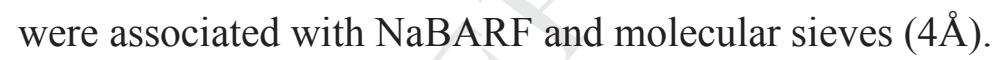

Keywords: O-H insertion catalysis; Copper; Chiral bisoxazoline; Enantioselectivity.

* Corresponding authors. E-mail addresses: paul.lemaux@univ-rennes1.fr (P. Le Maux); gerard.simonneaux@univ-rennes1.fr(G. Simonneaux). 


\section{Introduction}

Transition-metal-catalyzed heteroatom-hydrogen bond $(\mathrm{X}-\mathrm{H}, \mathrm{X}=\mathrm{N}, \mathrm{O}, \mathrm{S}, \mathrm{Si})$ insertion reactions that occur via a metal carbene or carbenoid intermediates represent one of the most efficient tools for the construction of $\mathrm{C}-\mathrm{X}$ bonds. ${ }^{1-5}$ Among various $\mathrm{X}-\mathrm{H}$ reactions, $\mathrm{N}-\mathrm{H}$ and $\mathrm{O}-\mathrm{H}$ insertion reactions have been the most studied and highly developed. ${ }^{6}$ This is particularly significant when one considers the importance of these functional groups in modern organic synthesis. Recently a number of enantioselective processes for carbenoid-based N-H and O-H insertions have been developed expanding the potential applicability of these methods. ${ }^{7-11}$ In particular, the enantioselective catalytic O-H insertion reaction provides chiral $\alpha$-alkyloxy, $\alpha$-aryloxy or $\alpha$-hydroxy esters and oxygen containing heterocyclic compounds, which are useful synthetic intermediates for the construction of natural products and biologically active molecules. ${ }^{12-14}$ The most significant advances in catalytic enantioselective $\mathrm{O}-\mathrm{H}$ insertion have been made in the past decade, although earlier efforts by Moody $^{15,16}$ and Landais ${ }^{17}$ to devise enantioselective or diastereoselective processes have been developed with only limited success. The first effective method was reported in 2006 by Maier and $\mathrm{Fu}^{18}{ }^{18}$ using a copper(II) chiral bisazaferrrocene catalyst in the insertion of $\alpha$-aryl- $\alpha$-diazoacetates into O-H bonds of simple alcohols and phenols to form $\alpha$-alkyl/aryloxyesters in high yield and up to $98 \%$ ee. Remarkably, Zhou and coll. found that copper(I) and iron(II) complexes of the chiral spiro bisoxazoline ligand are effective for asymmetric carbenoid insertion of $\omega$ hydroxy- $\alpha$-diazoesters into $\mathrm{O}-\mathrm{H}$ bonds of phenols, water and alcohols, to provide the corresponding $\mathrm{O}-\mathrm{H}$ inserted products with high enantioselectivitiy (up to $99.6 \%$ ). ${ }^{19-22}$ Uozumi and coworkers have also reported that copper(I) complex of the chiral imidazoindolephosphine ligand catalyzed the O-H insertion of carbenoids derived from $\alpha-$ diazopropionates into phenols to give the corresponding $\alpha$-aryloxy products with up to 
$91 \%$ ee. $^{23}$ These insertion reactions have been recently reviewed ${ }^{6}$ and the detailed mechanism of copper(I) carbenoid insertions into $\mathrm{O}-\mathrm{H}$ bond of water has been investigated using DFT calculations ${ }^{24}$ and NMR spectroscopy. ${ }^{25}$

Considering the chiral ligand, the use of $\mathrm{C}_{2}$ symmetric chiral bisoxazolines with a cyclic backbone as ligands in various metal-catalyzed enantiomeric reactions seems to give promising results, in particular with copper. ${ }^{26}$ Recently, we reported the application of a copper(I) catalytic system with such a ligand: a bicyclobisoxazoline ligand bearing a chiral dihydroethanoanthracene backbone ${ }^{27}\left(\mathrm{~L}^{*}\right)$ (Fig. 1) for asymmetric N-H insertion of $\alpha$-alkyl- $\alpha$-diazoesters with aniline derivatives. ${ }^{28}$ As a new development of our previous catalytic studies on N-H insertion of diazoesters, ${ }^{29-31}$ we describe herein a coppercatalyzed asymmetric $\mathrm{O}-\mathrm{H}$ insertion reaction into alkyl, aryl-alcohols of $\alpha$-alkyl- $\alpha$ diazoesters by using copper(I) and (II) complexes of chiral bicyclobisoxazoline ligand as catalysts.

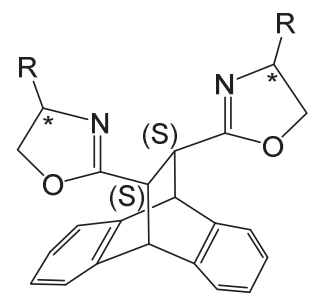

$\mathrm{L}^{*} \mathrm{R}=\mathrm{Ph}, i-\mathrm{Bu}, \mathrm{C}^{*}(\mathrm{R})$

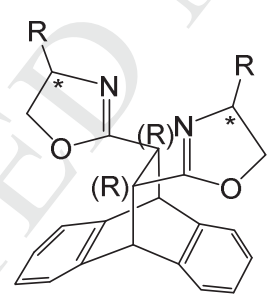

$\mathrm{L}^{*} \mathrm{R}=t-\mathrm{Bu}, \mathrm{C}^{*}(\mathrm{~S})$

Fig. 1. Structures of the chiral bicyclobisoxazoline ligands

\section{Results and discussion}

Previous studies realized on the copper-catalyzed asymmetric N-H insertion have demonstrated that the enantioselectivity was directly related to the anion of the copper precursor. $^{32,33}$ The smaller and stronger coordinating anions were found to be inferior to the larger and weaker coordinating anions for chiral induction. We therefore first tested a series of copper sources having various counteranions for the O-H insertion (Table 1). 
Among the different copper sources employed: $\mathrm{CuCl},\left[\mathrm{Cu}\left(\mathrm{CH}_{3} \mathrm{CN}\right)_{4}\right] \mathrm{PF}_{6}, \mathrm{CuOTf} .\left(\mathrm{C}_{6} \mathrm{H}_{6}\right)_{0.5}$ and $\mathrm{Cu}(\mathrm{OTf})_{2}$ in combination with $\mathrm{NaBARF}$ additive (entries 1,5,7 and 10), the precursor $\mathrm{Cu}(\mathrm{OTf})_{2}$ was the most efficient ( $62 \%$ yield and $90 \%$ ee, entry 10 ). With NaBARF, the ee increased from $13 \%$ to $59 \%$ for $\left[\mathrm{Cu}\left(\mathrm{CH}_{3} \mathrm{CN}\right)_{4}\right] \mathrm{PF}_{6}$ (entries 3 and 5 ), from $75 \%$ to $82 \%$ for CuOTf. $\left(\mathrm{C}_{6} \mathrm{H}_{6}\right)_{0.5}$ (entries 6 and 7) and from $75 \%$ to $90 \%$ for $\mathrm{Cu}(\mathrm{OTf})_{2}$ (entries 8 and 10). The addition of molecular sieves (4 $\AA$ MS) improved the yield of the reaction: 32 vs $60 \%$ for $\left[\mathrm{Cu}\left(\mathrm{CH}_{3} \mathrm{CN}\right)_{4}\right] \mathrm{PF}_{6}$ (entries 4 and 5) and 45 vs $62 \%$ for $\mathrm{Cu}(\mathrm{OTf})_{2}$ (entries 9 and 10). Uses of 5 equiv of phenol and $5 \mathrm{~mol} \%$ catalyst are necessary for obtaining the best yields.

Table 1. Optimization of the reaction conditions for the asymmetric O-H insertion of phenol with ethyl $\alpha$-diazopropionate in the presence of various copper catalysts ${ }^{\mathrm{a}}$

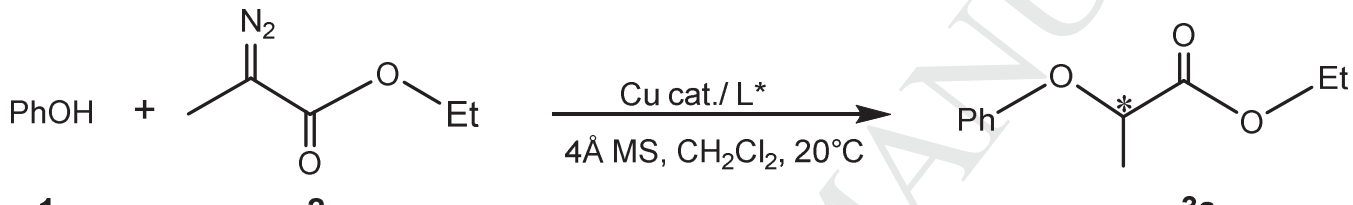

1

2

$3 \mathbf{a}$

\begin{tabular}{clcc}
\hline Entry & Copper source & ${\text { Yield }(\%)^{\mathrm{b}}}^{\mathrm{E}}$ & $\mathrm{Ee}(\%)^{\mathrm{c}}$ \\
\hline 1 & $\mathrm{CuCl}$ and $\mathrm{NaBAr}_{\mathrm{F}}$ & 17 & 25 \\
$2^{\mathrm{d}}$ & {$\left[\mathrm{Cu}\left(\mathrm{CH}_{3} \mathrm{CN}\right)_{4}\right] \mathrm{PF}_{6}$} & 5 & 15 \\
3 & {$\left[\mathrm{Cu}\left(\mathrm{CH}_{3} \mathrm{CN}\right)_{4}\right] \mathrm{PF}_{6}$} & 33 & 13 \\
$4^{\mathrm{d}}$ & {$\left[\mathrm{Cu}\left(\mathrm{CH}_{3} \mathrm{CN}\right)_{4}\right] \mathrm{PF}_{6}$ and $\mathrm{NaBAr}_{\mathrm{F}}$} & 32 & 29 \\
5 & {$\left[\mathrm{Cu}\left(\mathrm{CH}_{3} \mathrm{CN}\right)_{4}\right] \mathrm{PF}_{6}$ and $\mathrm{NaBAr}_{\mathrm{F}}$} & 60 & 59 \\
6 & $\mathrm{CuOTf} .\left(\mathrm{C}_{6} \mathrm{H}_{6}\right)_{0.5}$ & 73 & 75 \\
7 & $\mathrm{CuOTf} .\left(\mathrm{C}_{6} \mathrm{H}_{6}\right)_{0.5}$ and $\mathrm{NaBAr}_{\mathrm{F}}$ & 56 & 82 \\
8 & $\mathrm{Cu}(\mathrm{OTf})_{2}$ & 75 & 75 \\
$9^{\mathrm{d}}$ & $\mathrm{Cu}(\mathrm{OTf})_{2}$ and $\mathrm{NaBAr}_{\mathrm{F}}$ & 45 & 88 \\
10 & $\mathrm{Cu}(\mathrm{OTf})_{2}$ and $\mathrm{NaBAr}_{\mathrm{F}}$ & 62 & 90 \\
\hline
\end{tabular}

${ }^{a}$ Reaction conditions: Copper source $(5 \mu \mathrm{mol})$, ligand $\mathbf{L}^{*}(\mathrm{R}=\mathrm{Ph})(6 \mu \mathrm{mol})$ and NaBARF (6 $\mu \mathrm{mol})$ were mixed in $\mathrm{CH}_{2} \mathrm{Cl}_{2}(1 \mathrm{ml})$ for $1 \mathrm{~h}$ at $20^{\circ} \mathrm{C}$ in the presence of $100 \mathrm{mg}$ molecular sieves $(4 \AA)$, then phenol $(500 \mu \mathrm{mol})$ and ethyl $\alpha$-diazopropionate $(100 \mu \mathrm{mol})$ were sequentially introduced and the reaction mixture stirred for $1 \mathrm{~h}$ at $20^{\circ} \mathrm{C}$. ${ }^{b}$ Determined by GC. ${ }^{\mathrm{c}}$ Determined by GC equipped with a CP-Chirasil-Dex CB Column. ${ }^{\mathrm{d}}$ Without molecular sieves.

Under the optimized reaction conditions, a variety of substituted phenols were examined in the copper(II)-catalyzed asymmetric O-H insertion of $\alpha$-diazoesters (Table 2 ). The reaction of phenol with ethyl $\alpha$-diazopropionate at $20^{\circ} \mathrm{C}$ for $1 \mathrm{~h}$ gave the $\alpha$-aryloxycarboxylic esters 
compound 3a in $62 \%$ yield with $90 \%$ ee (entry 1). Ortho, meta and para-substituted phenols bearing electron-donating groups such as methyl group gave to the corresponding compounds, 3b, 3c and 3d in 49-77\% yield with $88-92 \%$ ee (entries 2, 3 and 4). When the phenol bearing ortho and meta-fluoro groups were used, the products $\mathbf{3 e}$ and $\mathbf{3 f}$ were obtained in low yield, 6 and $11 \%$ respectively with good enantioselectivities, 86 and $89 \%$ ee, respectively (entries 5 and 6). With the para-fluoro phenol, yield and enantioselectivity were $50 \%$ and $86 \%$ respectively (entry 7). High enantioselectivity of up to $94 \%$ was obtained with 1-naphtol and 49\% yield (entry 8). Aliphatic alcohols such as heptanol also underwent O-H insertion with a good yield, $88 \%$ (entry 9) but the enantioselectivity was low, 28\%. Bulky diazo such as tbutyl diazopropionate was also evaluated vs two substrates (phenol and p-fluorophenol). These two results have been summarized in Table 2 (lines $3 \mathrm{j}$ and $3 \mathrm{k}$ ). The use of these bulky diazo derivatives do not change importantly the reactivity and the selectivity, probably because the $t$-bu group is too far away from the carbene carbon atom.

The influence of different substituents of the oxazoline rings of the ligand $\mathrm{L}^{*}$ on the yield and enantioselectivity of the $\mathrm{O}-\mathrm{H}$ insertion reaction was also examined. Both yields and enantioselectivities were improved from an i-butyl (46\% yield, $78 \%$ ee) to $t$-butyl (55\% yield, $84 \%$ ee) and phenyl (62\% yield, $90 \%$ ee) (entries 10,11 and 1$)$ using phenol as substrate. 
Table 2. $\mathrm{Cu}(\mathrm{II})$ catalytic asymmetric $\mathrm{O}-\mathrm{H}$ insertion of alcohols with ethyl and $t$-butyl $\alpha$ diazopropionate $^{\mathrm{a}}$

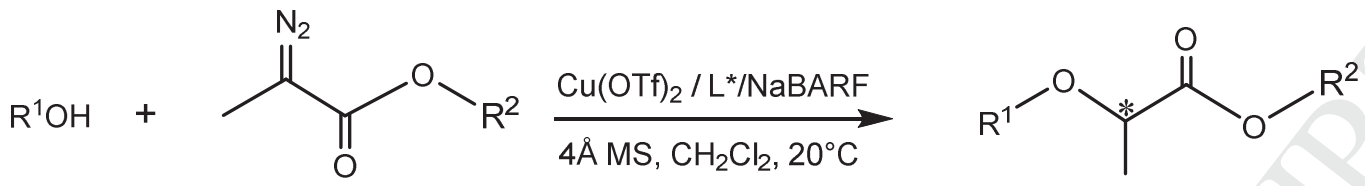

1

2

3

\begin{tabular}{ccccccl}
\hline Entry & $\mathrm{L}^{*} \mathrm{R}=$ & $\mathrm{R}^{\mathrm{l}}$ & $\mathrm{R}^{2}$ & Product & Yield (\%) & Ee (\%) \\
\hline 1 & $\mathrm{Ph}$ & $\mathrm{Ph}$ & $\mathrm{Et}$ & $\mathbf{3 a}$ & 62 & $90(\mathrm{~S})^{\mathrm{d}}$ \\
2 & $\mathrm{Ph}$ & $o-\mathrm{MeC}_{6} \mathrm{H}_{4}$ & $\mathrm{Et}$ & $\mathbf{3 b}$ & 49 & 88 \\
3 & $\mathrm{Ph}$ & $m-\mathrm{MeC}_{6} \mathrm{H}_{4}$ & $\mathrm{Et}$ & $\mathbf{3 c}$ & 52 & 92 \\
4 & $\mathrm{Ph}$ & $p-\mathrm{MeC}_{6} \mathrm{H}_{4}$ & $\mathrm{Et}$ & $\mathbf{3 d}$ & 77 & 90 \\
5 & $\mathrm{Ph}$ & $o-\mathrm{FC}_{6} \mathrm{H}_{4}$ & $\mathrm{Et}$ & $\mathbf{3 e}$ & 6 & 86 \\
6 & $\mathrm{Ph}$ & $m-\mathrm{FC}_{6} \mathrm{H}_{4}$ & $\mathrm{Et}$ & $\mathbf{3 f}$ & 11 & 89 \\
7 & $\mathrm{Ph}$ & $p-\mathrm{FC}_{6} \mathrm{H}_{4}$ & $\mathrm{Et}$ & $\mathbf{3 g}$ & 50 & 86 \\
8 & $\mathrm{Ph}$ & $1-$ naphthyl & $\mathrm{Et}$ & $\mathbf{3 h}$ & 49 & $94(\mathrm{~S})^{\mathrm{d}}$ \\
9 & $\mathrm{Ph}$ & $\mathrm{Heptyl}$ & $\mathrm{Et}$ & $\mathbf{3 i}$ & 88 & 28 \\
10 & $i-\mathrm{Bu}$ & $\mathrm{Ph}$ & $\mathrm{Et}$ & $\mathbf{3 a}$ & 46 & 78 \\
11 & $t-\mathrm{Bu}$ & $\mathrm{Ph}$ & $\mathrm{Et}$ & $\mathbf{3 a}$ & 55 & $84(\mathrm{R})^{\mathrm{d}}$ \\
12 & $\mathrm{Ph}$ & $\mathrm{Ph}$ & $t-\mathrm{Bu}$ & $\mathbf{3 j}$ & 82 & $90^{\mathrm{e}}$ \\
13 & $\mathrm{Ph}$ & $p-\mathrm{FC}_{6} \mathrm{H}_{4}$ & $t-\mathrm{Bu}$ & $\mathbf{3 k}$ & 70 & $83^{\mathrm{e}}$ \\
\hline
\end{tabular}

${ }^{a}$ Reaction conditions: $\mathrm{Cu}(\mathrm{II})(\mathrm{OTf})_{2}(5 \mu \mathrm{mol})$, ligand $\mathbf{L}^{*}(6 \mu \mathrm{mol})$ and NaBARF $(6 \mu \mathrm{mol})$ were mixed in $\mathrm{CH}_{2} \mathrm{Cl}_{2}(1 \mathrm{ml})$ for $30 \mathrm{mn}$ at $20^{\circ} \mathrm{C}$ in the presence of $100 \mathrm{mg}$ molecular sieves $(4 \AA)$, then alcohol $(500 \mu \mathrm{mol})$ and ethyl $\alpha$-diazopropionate $(100 \mu \mathrm{mol}))$ were sequentially introduced and the reaction mixture stirred for $1 \mathrm{~h}$ at $20^{\circ} \mathrm{C} .{ }^{b}$ Determined by GC. ${ }^{\mathrm{c}}$ Determined by GC equipped with a CP-Chirasil-Dex CB Column. ${ }^{\mathrm{d}}$ The absolute configuration was determined by comparison of the optical rotation with the Ref $19 .{ }^{\mathrm{e}}$ Determined by chiral HPLC on a Lux-Cellulose- 3 column.

For comparison, the asymmetric $\mathrm{O}-\mathrm{H}$ insertion catalyzed by $\mathrm{Cu}(\mathrm{I})$ complexes was also examined under the same reaction conditions. As can be seen in Table 3, the yields are inferior to those obtained with $\mathrm{Cu}(\mathrm{II})$ (Table 2). For examples, with phenol, $p$-cresol, $p$-fluoro phenol and 1-naphtol, the yield was in the range of 33-63\% (entries 3, 5, 7, and 9, Table 3) for copper (I) whereas a range of 49-77\% was observed for copper(II) (entries 1, 4, 7 and 8, Table 2). As previously reported for $\mathrm{Cu}(\mathrm{II})$ in Table 2, the addition of NaBARF (see Table 3) also enhances the enantioselectivity from $75 \%$ to $86 \%$ ee with the phenol (entries 1 and 3), from $74 \%$ to $89 \%$ ee with the $p$-cresol (entries 4 and 5), from $74 \%$ to $81 \%$ ee with the $p$-fluoro 
phenol (entries 6 and 7), from 72\% to 92\% with the 1-naphtol (entries 8 and 9). The enantiomeric excesses were similar to those obtained in the reactions with $\mathrm{Cu}(\mathrm{II})$. For example, it is observed in Table 3, 86 vs $90 \%$ with the phenol (entry 3), 92 vs $94 \%$ with the 1 naphtol (entry 9). On a mechanistic viewpoint, the little difference in enantioselectivity between $\mathrm{Cu}(\mathrm{I})$ and $\mathrm{Cu}(\mathrm{II})$ suggests that the active catalyst generated from $\mathrm{Cu}(\mathrm{I})$ and $\mathrm{Cu}(\mathrm{II})$ precursors is probably the same entity.

In order to obtain information on the catalyst structure, a study by electrospray ionization mass spectrometry (ESI-MS) was undertaken. ESI-MS of a solution prepared in situ from $\mathrm{Cu}(\mathrm{II})(\mathrm{OTf})_{2}$ and the ligand $\mathrm{L}^{*}$ revealed the presence of two major species at $\mathrm{m} / \mathrm{z} 1055.3584$, $\left[\mathrm{CuL}_{2}\right]^{+}$and $\mathrm{m} / \mathrm{z}$ 1205.5947, $\left[\mathrm{CuL}_{2}^{*}, \mathrm{CF}_{3} \mathrm{SO}_{3}{ }^{-}\right]^{+}$. In contrast to our previous studies however, ${ }^{28}$ no $\left[\mathrm{CuL}^{*}\right]$ species was detected. To complement this point, an experiment using paracresol as substrate and a ratio $\mathrm{Cu}: \mathrm{L}=1: 2$ was realized to check a possible involvement of such species. After one hour, the yield was only $22 \%(\mathrm{ee}=87 \%$ ) whereas a yield of $77 \%$ (ee $=90 \%$ ) was obtained with a ratio $\mathrm{Cu}: \mathrm{L}=1: 1$ (line 4 , Table 2). Thus an inhibition of the catalytic reaction is observed in presence of 2 equivalents of $\mathrm{L}$. Therefore a ratio $\mathrm{Cu}: \mathrm{L}=1: 1$ was chosen in the following scheme (vide infra).

In the copper-catalyzed insertion reaction, the carbene pathway is predominant and the $\mathrm{Cu}$ complex generally acts as a carbene-tranfer. For $\mathrm{Cu}(\mathrm{II})$-system, however, the work of Salomon and Kochi ${ }^{34}$ shows that it is very difficult to identify the oxidation state of the active $\mathrm{Cu}$ used as catalyst. One example with copper(II)/bisazaferrocene was previously reported by $\mathrm{Fu}^{18}$ but without detailed mechanistic studies. A possible reduction of the $\mathrm{Cu}(\mathrm{II})$-catalyst to $\mathrm{Cu}(\mathrm{I})$ by the diazoester was also suggested during the course of the reaction by $\mathrm{Kochi}^{34}$ and Fraile. ${ }^{35}$ Concerning the $\mathrm{Cu}$ oxidation state in our experiments, we check by proton NMR the addition of diazo derivatives onto $\mathrm{Cu}(\mathrm{I}) \mathrm{L}^{*}$ and $\mathrm{Cu}(\mathrm{II}) \mathrm{L}^{*}$ species (ratio $\mathrm{Cu} ; \mathrm{L}=1 / 1$ ). It was 
not clear that $\mathrm{Cu}(\mathrm{II})$ is reduced in the NMR tube. Thus we do not have direct evidence of the reduction of $\mathrm{Cu}$ (II) during the course of the catalytic reaction and consequently, this aspect will not further developed.

It is generally accepted that insertions into $\mathrm{X}-\mathrm{H}$ bond bearing lone-pair electrons on the $\mathrm{X}$ atom most likely proceed by a stepwise ylide mechanism. ${ }^{36}$ As it has already been seen in the $\mathrm{N}-\mathrm{H}$ insertion, the possible mechanism involves the formation of an electron-deficient carbene and its insertion into the N-H bond via a copper-associated ylide intermediate. ${ }^{36}$ Although we have not yet conducted detailed mechanistic studies, we can suggest in the O-H insertion reaction that a copper-associated ylide is formed by attack of the lone-pair electrons of the phenol $\mathrm{O}$ atom onto the electron-deficient copper carbene and then simultaneous proton transfer and dissociation of the chiral copper-catalyst to yield the insertion product. Because the chiral catalyst is involved during the process, chiral induction can be expected and so high enantioselectivities obtained.

Table 3. $\mathrm{Cu}(\mathrm{I})$ catalytic asymmetric $\mathrm{O}-\mathrm{H}$ insertion of alcohols with ethyl $\alpha$-diazopropionate ${ }^{\mathrm{a}}$<smiles></smiles>

\begin{tabular}{cccccc}
\hline Entry & $\mathrm{L}^{*} \mathrm{R}=$ & $\mathrm{R}^{1}$ & Product & Yield (\%) $^{\mathrm{b}}$ & Ee (\%) \\
\hline 1 & $\mathrm{Ph}$ & $\mathrm{Ph}$ & 3a & 73 & 75 \\
$2^{\mathrm{d}}$ & $\mathrm{Ph}$ & $\mathrm{Ph}$ & 3a & 38 & 62 \\
$3^{\mathrm{e}}$ & $\mathrm{Ph}$ & $\mathrm{Ph}$ & 3a & 56 & 86 \\
4 & $\mathrm{Ph}$ & $p-\mathrm{MeC}_{6} \mathrm{H}_{4}$ & 3d & 76 & 74 \\
$5^{\mathrm{e}}$ & $\mathrm{Ph}$ & $p-\mathrm{MeC}_{6} \mathrm{H}_{4}$ & $\mathbf{3 d}$ & 63 & 89 \\
6 & $\mathrm{Ph}$ & $p-\mathrm{FC}_{6} \mathrm{H}_{4}$ & $\mathbf{3 g}$ & 56 & 74 \\
$7^{\mathrm{e}}$ & $\mathrm{Ph}$ & $p-\mathrm{FC}_{6} \mathrm{H}_{4}$ & $\mathbf{3 g}$ & 33 & 81 \\
8 & $\mathrm{Ph}$ & $1-$ naphthyl & $\mathbf{3 h}$ & 56 & 72 \\
$9^{\mathrm{e}}$ & $\mathrm{Ph}$ & 1-naphthyl & $\mathbf{3 h}$ & 44 & 92 \\
10 & $\mathrm{Ph}$ & Heptyl & $\mathbf{3 i}$ & 89 & 36 \\
\hline
\end{tabular}

${ }^{\mathrm{a}}$ Reaction conditions: $\mathrm{Cu}(\mathrm{I}) \mathrm{OTf}(5 \mu \mathrm{mol})$ and ligand $\mathbf{L}^{*}(6 \mu \mathrm{mol})$ were mixed in $\mathrm{CH}_{2} \mathrm{Cl}_{2}(1$ $\mathrm{ml})$ for $1 \mathrm{~h}$ at $25^{\circ} \mathrm{C}$ in the presence of $100 \mathrm{mg}$ molecular sieves $(4 \AA)$, then phenol $(500 \mu \mathrm{mol})$ and ethyl $\alpha$-diazopropionate $(100 \mu \mathrm{mol})$ were introduced and stirred for $1 \mathrm{~h}$ at $25^{\circ} \mathrm{C}$. 
Determined by GC. ${ }^{c}$ Determined by GC equipped with a CP-Chirasil-Dex CB Column. ${ }^{\mathrm{d}}$

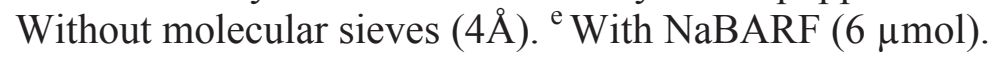

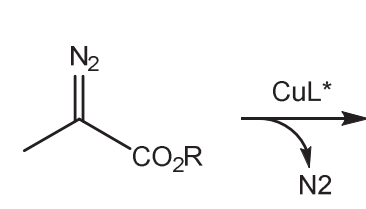

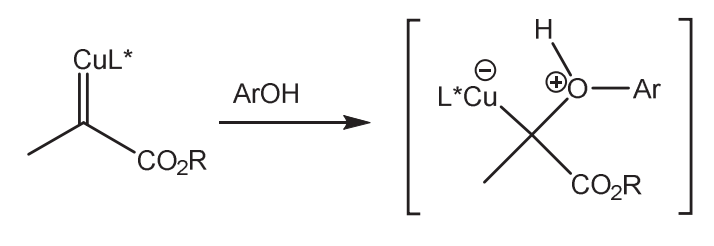<smiles>[R]OC(C)COC(=O)O</smiles>
metal-associated-ylide

Scheme 1. Proposed mechanism for copper-catalyzed O-H insertion

\section{Conclusion}

In summary, we have developed a new $\mathrm{Cu}(\mathrm{I})$ or $\mathrm{Cu}(\mathrm{II})$-bicyclobisoxazoline-catalyst system for the asymmetric insertion of $\alpha$-diazocarbonyl compounds into the $\mathrm{O}-\mathrm{H}$ bond of different aryl and alkyl alcohols under mild conditions. Good yields and high enantioselectivities of up to $94 \%$ ee can be obtained when the catalyst is associated with NaBARF in the presence of molecular sieves $(4 \AA)$. A comparative study between $\mathrm{Cu}(\mathrm{I})$ and $\mathrm{Cu}$ (II)-catalysts activity in the $\mathrm{O}-\mathrm{H}$ insertion reaction shows that the efficiency of these catalysts is very close. Accordingly, it seems reasonable to think that the same active species is implicated in the reaction. A stepwise insertion mechanism involving simultaneous proton transfer and catalyst dissociation as major pathway has been proposed. Possible application of these new chiral ligands using iron or ruthenium complexes ${ }^{22,37}$ for the insertion reaction into $\mathrm{O}-\mathrm{H}$ bond can be expected in the near future..

\section{Experimental}

\subsection{General}

All reactions were performed under argon. Solvents were distilled from an appropriate drying agent prior to use: $\mathrm{CH}_{2} \mathrm{Cl}_{2}$ from $\mathrm{CaH}_{2}$. Commercially available reagents were used without further purification unless otherwise stated. All reactions were monitored by TLC with Merck precoated aluminum foil sheets (Silica gel 60 with fluorescent indicator UV254). Compounds 
were visualized with UV light at $254 \mathrm{~nm}$. Column chromatographies were carried out using silica gel from Merck (0.063-0.200 mm). ${ }^{1} \mathrm{H}$ NMR and ${ }^{13} \mathrm{C} \mathrm{NMR}$ in $\mathrm{CDCl}_{3}$ were recorded using Bruker (Advance 400dpx spectrometer) at $400 \mathrm{MHz}$ and $125 \mathrm{MHz}$, respectively. High resolution mass spectra were recorded on a Thermo-Fisher Q-Exactive (Q-Tof 2) spectrometer in ESI positif mode at the CRMPO at Rennes. All catalytic reactions were controlled on a Varian CP-3380 GC system that was equipped with a CP-Chirasil-Dex Column (25m, $0.25 \mathrm{~mm}$ I.D.) The chiral HPLC analyses were performed at the Plateforme de chromatographie chirale at Aix-Marseille Université on an Agilent 1260 Infinity unit (pump G1311B, autosampler G1329B, DAD G1315D), with Igloo-Cil ovens, monitored by SRA Instruments Seleccol software (Version 1.2.3.0), Agilent OpenLAB CDS Chemstation LC and CE Drivers (A.02.08SP1) and Agilent OpenLAB Intelligent reporting (A.01.06.111). Chiroptical detection was used with Jasco OR-1590 and CD-2095, polarimetric and circular dichroism detectors. The sign given by the on-line circular dichroïsm at $254 \mathrm{~nm}$ is the sign of the compound in the solvent used for the chromatographic separation. The sign given by the on-line polarimeter is the sign of the compound in the solvent used for the chromatographic separation. The analytical column $(250 \times 4.6 \mathrm{~mm})$ used is Lux-Cellulose3 from Phenomenex (Le Pecq, France), cellulose tris-(4-methylbenzoate) coated on silica. Heptane and $i$-PrOH, HPLC grade, were degassed and filtered on a $0.45 \mathrm{~m}$ millipore membrane before use. The optical rotations were recorded on a PerkinElmer model 341 polarimeter. The bis(oxazoline) ligands $\mathrm{L}^{*}$ was synthetized as previously described in the literature. $^{26,38}$ The alkyl $\alpha$-diazopropionate were prepared according to procedures described in the literature..$^{23,32}$

\subsection{General procedure for asymmetric $\mathrm{O}-\mathrm{H}$ insertion reaction}


$\mathrm{Cu}(\mathrm{II})(\mathrm{OTf})_{2}$ or $\mathrm{Cu}(\mathrm{I})(\mathrm{OTf})(5 \mu \mathrm{mol})$, ligand $\mathbf{L}^{*}(6 \mu \mathrm{mol})$ and NaBARF $(6 \mu \mathrm{mol})$ were mixed in $\mathrm{CH}_{2} \mathrm{Cl}_{2}(1 \mathrm{ml})$ for $30 \mathrm{mn}$ at $20^{\circ} \mathrm{C}$ in the presence of $100 \mathrm{mg}$ molecular sieves $(4 \AA)$, then alcohol $(500 \mu \mathrm{mol})$ and ethyl $\alpha$-diazopropionate $(100 \mu \mathrm{mol}))$ were sequentially introduced and the reaction mixture stirred for $1 \mathrm{~h}$ at $20^{\circ} \mathrm{C}$. The insertion yield was determined by GC analysis on the crude reaction mixture. After purification by flash chromatography on silica gel $($ ethyl acetate/hexane $=0.1 / 9.9)$, the enantiomeric excess of the insertion product was determined by chiral GC equipped with a CP-Chirasil-Dex CB Column.

\subsection{Analytical data for $\mathrm{O}-\mathrm{H}$ insertion products}

(S)-(-)-Ethyl 2-phenoxypropionate 3a. Yield: 62\%; ${ }^{1} \mathrm{H} \mathrm{NMR}\left(\mathrm{CDCl}_{3}\right): \delta=1.27(\mathrm{t}, 3 \mathrm{H}), 1.64$ $(\mathrm{d}, 3 \mathrm{H}), 4.24(\mathrm{q}, 2 \mathrm{H}), 4.77(\mathrm{q}, 1 \mathrm{H}), 6.90(\mathrm{~d}, 2 \mathrm{H}), 6.99(\mathrm{t}, 1 \mathrm{H}), 7.29(\mathrm{t}, 2 \mathrm{H}) ;{ }^{13} \mathrm{C}$ NMR $\left(\mathrm{CDCl}_{3}\right): 14.12,18.57,61.26,72.63,115.12,121.55,129.52,157.61,172.27 ;[\alpha]^{20}{ }_{\mathrm{D}}=-41.3(\mathrm{c}$ $\left.0.8, \mathrm{CHCl}_{3}\right)$; ee $=90 \%\left(\mathrm{GC}\right.$ conditions: CP-Chirasil-Dex column, $100^{\circ} \mathrm{C}(1 \mathrm{~min}), 2.5^{\circ} \mathrm{C} \mathrm{min}^{-1}$ $100-180^{\circ} \mathrm{C}, t_{\mathrm{R}}=12.04 \mathrm{~min}$ for minor isomer, $t_{\mathrm{R}}=12.22 \mathrm{~min}$ for major isomer). HRESIMS (m/z) calcd for $\mathrm{C}_{11} \mathrm{H}_{14} \mathrm{O}_{3} \mathrm{Na}: 217.08406[\mathrm{M}+\mathrm{Na}]^{+}$, found: 217.0842 .

(-)-Ethyl 2-(o-tolyloxy)propionate 3b. Yield: 49\%; ${ }^{1} \mathrm{H}$ NMR $\left(\mathrm{CDCl}_{3}\right): \delta=1.27(\mathrm{t}, 3 \mathrm{H}), 1.66$ $(\mathrm{d}, 3 \mathrm{H}), 2.31(\mathrm{~s}, 3 \mathrm{H}), 4.23(\mathrm{q}, 2 \mathrm{H}), 4.76(\mathrm{q}, 1 \mathrm{H}), 6.71(\mathrm{~d}, 1 \mathrm{H}), 6.90(\mathrm{t}, 1 \mathrm{H}), 7.12(\mathrm{t}, 1 \mathrm{H}), 7.17$ $(\mathrm{d}, 1 \mathrm{H}) ;{ }^{13} \mathrm{C} \mathrm{NMR}\left(\mathrm{CDCl}_{3}\right): 14.12,16.29,18.68,61.15,72.97,112.02,121.25,126.62$, $127.54,130.97,155.95,172.42 ;[\alpha]^{20}{ }_{\mathrm{D}}=-25.1\left(\mathrm{c} 0.8, \mathrm{CHCl}_{3}\right)$; ee $=88 \%(\mathrm{GC}$ conditions: $\mathrm{CP}-$ Chirasil-Dex column, $100^{\circ} \mathrm{C}(1 \mathrm{~min}), 2.5^{\circ} \mathrm{C} \min ^{-1} 100-180^{\circ} \mathrm{C}, t_{\mathrm{R}}=13.61 \mathrm{~min}$ for minor isomer, $t_{\mathrm{R}}=13.88 \mathrm{~min}$ for major isomer). $\operatorname{HRESIMS~}(\mathrm{m} / \mathrm{z})$ calcd for $\mathrm{C}_{12} \mathrm{H}_{16} \mathrm{O}_{3} \mathrm{Na}$ : 231.09971 $[\mathrm{M}+\mathrm{Na}]^{+}$, found: 231.0997 .

(-)-Ethyl 2-(m-tolyloxy)propionate 3c. Yield: 52\%; ${ }^{1} \mathrm{H}$ NMR $\left(\mathrm{CDCl}_{3}\right): \delta=1.27(\mathrm{t}, 3 \mathrm{H}), 1.63$ $(\mathrm{d}, 3 \mathrm{H}), 2.33(\mathrm{~s}, 3 \mathrm{H}), 4.24(\mathrm{q}, 2 \mathrm{H}), 4.75(\mathrm{q}, 1 \mathrm{H}), 6.69(\mathrm{~d}, 1 \mathrm{H}), 6.74(\mathrm{~s}, 1 \mathrm{H}), 6.81(\mathrm{~d}, 1 \mathrm{H}), 7.17$ 
$(\mathrm{t}, 2 \mathrm{H}) ;{ }^{13} \mathrm{C} \mathrm{NMR}\left(\mathrm{CDCl}_{3}\right): 14.14,18.59,21.49,61.21,72.55,111.81,116.11,122.39,129.22$, 139.60, 157.61, 172.39; $[\alpha]^{20}{ }_{\mathrm{D}}=-40.1\left(\mathrm{c} 0.8, \mathrm{CHCl}_{3}\right)$; ee $=92 \%(\mathrm{GC}$ conditions: CP-ChirasilDex column, $100^{\circ} \mathrm{C}(1 \mathrm{~min}), 2.0^{\circ} \mathrm{C} \min ^{-1} 100-180^{\circ} \mathrm{C}, t_{\mathrm{R}}=16.37 \mathrm{~min}$ for minor isomer,$t_{\mathrm{R}}=$ $16.55 \mathrm{~min}$ for major isomer). HRESIMS $(\mathrm{m} / \mathrm{z})$ calcd for $\mathrm{C}_{12} \mathrm{H}_{16} \mathrm{O}_{3} \mathrm{Na}: 231.09971[\mathrm{M}+\mathrm{Na}]^{+}$, found: 231.0997.

(-)-Ethyl 2-(p-tolyloxy)propionate 3d. Yield: 77\%; ${ }^{1} \mathrm{H}$ NMR $\left(\mathrm{CDCl}_{3}\right): \delta=1.27(\mathrm{t}, 3 \mathrm{H}), 1.63$ $(\mathrm{d}, 3 \mathrm{H}), 2.30(\mathrm{~s}, 3 \mathrm{H}), 4.24(\mathrm{q}, 2 \mathrm{H}), 4.72(\mathrm{q}, 1 \mathrm{H}), 6.80(\mathrm{~d}, 2 \mathrm{H}), 7.09(\mathrm{~d}, 2 \mathrm{H}) ;{ }^{13} \mathrm{C}$ NMR $\left(\mathrm{CDCl}_{3}\right): 14.13,18.58,20.48,61.20,72.86,115.06,129.95,139.85,155.50,172.39 ;[\alpha]^{20}{ }_{\mathrm{D}}=-$ $41.1\left(\right.$ c $\left.0.9, \mathrm{CHCl}_{3}\right)$; ee $=90 \%$ (GC conditions: CP-Chirasil-Dex column, $100^{\circ} \mathrm{C}(1 \mathrm{~min})$, $2.5^{\circ} \mathrm{C} \min ^{-1} 100-180^{\circ} \mathrm{C}, t_{\mathrm{R}}=15.68 \mathrm{~min}$ for minor isomer, $t_{\mathrm{R}}=15.94 \mathrm{~min}$ for major isomer). $\operatorname{HRESIMS}(\mathrm{m} / \mathrm{z})$ calcd for $\mathrm{C}_{12} \mathrm{H}_{16} \mathrm{O}_{3} \mathrm{Na}: 231.09971[\mathrm{M}+\mathrm{Na}]^{+}$, found: 231.0997.

(-)-Ethyl 2-(o-fluorophenoxy)propionate 3e. Yield: $6 \% ;{ }^{1} \mathrm{H} \mathrm{NMR}\left(\mathrm{CDCl}_{3}\right): \delta=1.28(\mathrm{t}, 3 \mathrm{H})$, $1.68(\mathrm{~d}, 3 \mathrm{H}), 4.27(\mathrm{q}, 2 \mathrm{H}), 4.79(\mathrm{q}, 1 \mathrm{H}), 6.85-6.90(\mathrm{~m}, 2 \mathrm{H}), 7.02-7.07(\mathrm{~m}, 2 \mathrm{H}) ;[\alpha]^{20}{ }_{\mathrm{D}}=-16.7$ (c $\left.0.12, \mathrm{CHCl}_{3}\right)$; ee $=86 \%$ (GC conditions: $\mathrm{CP}-$ Chirasil-Dex column, $100^{\circ} \mathrm{C}(1 \mathrm{~min}), 2.5^{\circ} \mathrm{C}$ $\min ^{-1} 100-180^{\circ} \mathrm{C}, t_{\mathrm{R}}=11.88 \mathrm{~min}$ for minor isomer,$t_{\mathrm{R}}=12.09 \mathrm{~min}$ for major isomer). HRESIMS $(\mathrm{m} / \mathrm{z})$ calcd for $\mathrm{C}_{11} \mathrm{H}_{13} \mathrm{O}_{3} \mathrm{FNa}$ : 235.07464 [M + Na] $]^{+}$, found: 235.0744.

(-)-Ethyl 2-(m-fluorophenoxy)propionate 3f. Yield: $11 \% ;{ }^{1} \mathrm{H}$ NMR $\left(\mathrm{CDCl}_{3}\right): \delta=1.28(\mathrm{t}$, $3 \mathrm{H}), 1.64(\mathrm{~d}, 3 \mathrm{H}), 4.25(\mathrm{q}, 2 \mathrm{H}), 4.74(\mathrm{q}, 1 \mathrm{H}), 6.61-6.72(\mathrm{~m}, 2 \mathrm{H}), 7.55(\mathrm{t}, 1 \mathrm{H}), 7.73(\mathrm{dd}, 1 \mathrm{H})$; $[\alpha]^{20}{ }_{\mathrm{D}}=-20.8\left(\mathrm{c} 0.15, \mathrm{CHCl}_{3}\right)$; ee $=89 \%\left(\mathrm{GC}\right.$ conditions: $\mathrm{CP}-\mathrm{Chirasil-Dex}$ column, $100^{\circ} \mathrm{C}(1$ $\min ), 2.5^{\circ} \mathrm{C} \min ^{-1} 100-180^{\circ} \mathrm{C}, t_{\mathrm{R}}=12.78 \mathrm{~min}$ for minor isomer,$t_{\mathrm{R}}=12.98 \mathrm{~min}$ for major isomer). HRESIMS (m/z) calcd for $\mathrm{C}_{11} \mathrm{H}_{13} \mathrm{O}_{3} \mathrm{FNa}$ : 235.07464 [M+ Na] $]^{+}$, found: 235.0744.

(-)-Ethyl 2-(p-fluorophenoxy)propionate 3g. Yield: 50\%; ${ }^{1} \mathrm{H} \mathrm{NMR}\left(\mathrm{CDCl}_{3}\right): \delta=1.27(\mathrm{t}$, $3 \mathrm{H}), 1.63(\mathrm{~d}, 3 \mathrm{H}), 4.24$ (q, 2H), 4.69 (q, 1H), 6.84-6.87 (m, 2H), 6.96-7.0 (m, 2H); ${ }^{13} \mathrm{C}$ NMR $\left(\mathrm{CDCl}_{3}\right): 14.12,18.55,61.32,73.48,115.79,116.02,116.43,116.50,172.05 ;[\alpha]^{20}{ }_{\mathrm{D}}=-23.3(\mathrm{c}$ 
0.6, $\mathrm{CHCl}_{3}$; ee $=86 \%\left(\mathrm{GC}\right.$ conditions: $\mathrm{CP}-$ Chirasil-Dex column, $100^{\circ} \mathrm{C}(1 \mathrm{~min}), 2.5^{\circ} \mathrm{C} \mathrm{min}^{-1}$ $100-180^{\circ} \mathrm{C}, t_{\mathrm{R}}=12.35 \mathrm{~min}$ for minor isomer,$t_{\mathrm{R}}=12.71 \mathrm{~min}$ for major isomer). HRESIMS (m/z) calcd for $\mathrm{C}_{11} \mathrm{H}_{13} \mathrm{O}_{3} \mathrm{FNa}$ : $235.07464[\mathrm{M}+\mathrm{Na}]^{+}$, found: 235.0744 .

(S)-(+)-Ethyl 2-(naphthalen-1-yloxy)propionate 3h. Yield: 49\%; ${ }^{1} \mathrm{H}$ NMR $\left(\mathrm{CDCl}_{3}\right): \delta=$ $1.26(\mathrm{t}, 3 \mathrm{H}), 1.78(\mathrm{~d}, 3 \mathrm{H}), 4.25(\mathrm{q}, 2 \mathrm{H}), 4.96(\mathrm{q}, 1 \mathrm{H}), 6.73(\mathrm{~d}, 1 \mathrm{H}), 7.35(\mathrm{t}, 1 \mathrm{H}), 7.47-7.53(\mathrm{~m}$, 3H), $7.82(\mathrm{t}, 1 \mathrm{H}), 8.38(\mathrm{t}, 1 \mathrm{H}) ;{ }^{13} \mathrm{C} \mathrm{NMR}\left(\mathrm{CDCl}_{3}\right): 14.12,18.64,61.27,73.13,105.71,121.14$, $122.31,125.34,125.53,126.51,127.38,134.64,172.23 ;[\alpha]^{20}{ }_{D}=+32 .\left(\mathrm{c} 0.9, \mathrm{CHCl}_{3}\right)$; ee $=$ 94\% (GC conditions: CP-Chirasil-Dex column, $100^{\circ} \mathrm{C}(1 \mathrm{~min}), 1^{\circ} \mathrm{C} \min ^{-1} 100-180^{\circ} \mathrm{C}, t_{\mathrm{R}}=$ $58.17 \mathrm{~min}$ for minor isomer, $t_{\mathrm{R}}=58.76 \mathrm{~min}$ for major isomer). HRESIMS $(\mathrm{m} / \mathrm{z}) \mathrm{calcd}$ for $\mathrm{C}_{15} \mathrm{H}_{16} \mathrm{O}_{3} \mathrm{FNa}: 267.09916[\mathrm{M}+\mathrm{Na}]^{+}$, found: 267.0990

(-)-Ethyl 2-(p-heptyloxy)propionate 3i. Yield: $88 \%$; ${ }^{1} \mathrm{H}$ NMR $\left(\mathrm{CDCl}_{3}\right): \delta=0.89,1.29-1.34$ $(\mathrm{m}, 8 \mathrm{H}), 1.41(\mathrm{~d}, 3 \mathrm{H}), 1.62(\mathrm{q}, 2 \mathrm{H}), 3.37(\mathrm{q}, 1 \mathrm{H}), 3.57(\mathrm{q}, 1 \mathrm{H}), 3.95(\mathrm{q}, 1 \mathrm{H}), 4.16-4.28(\mathrm{~m}$, $2 \mathrm{H}) ;{ }^{13} \mathrm{C} \mathrm{NMR}\left(\mathrm{CDCl}_{3}\right): 14.06,18.68,22.60,26.00,29.10,29.74,31.78,53.40,60.70,70.42$, $75.01 ;[\alpha]^{20}{ }_{\mathrm{D}}=-16.0\left(\mathrm{c} 1, \mathrm{CHCl}_{3}\right)$; ee $=28 \%(\mathrm{GC}$ conditions: CP-Chirasil-Dex column, $120^{\circ} \mathrm{C}(1 \mathrm{~min}), 2.5^{\circ} \mathrm{C} \min ^{-1} 120-180^{\circ} \mathrm{C}, t_{\mathrm{R}}=7.12 \mathrm{~min}$ for minor isomer, $t_{\mathrm{R}}=7.23 \mathrm{~min}$ for major isomer). HRESIMS $(\mathrm{m} / \mathrm{z})$ calcd for $\mathrm{C}_{12} \mathrm{H}_{24} \mathrm{O}_{3} \mathrm{Na}: 239.16231[\mathrm{M}+\mathrm{Na}]^{+}$, found: 239.1621 .

(-)-t-Bu 2-phenoxypropionate 3j. Yield: 82\%; ${ }^{1} \mathrm{H}$ NMR $\left(\mathrm{CDCl}_{3}\right): \delta=1.46(\mathrm{~s}, 9 \mathrm{H}), 1.61(\mathrm{~d}$, $3 \mathrm{H}), 4.65(\mathrm{q}, 1 \mathrm{H}), 6.89(\mathrm{~d}, 2 \mathrm{H}), 6.98(\mathrm{t}, 1 \mathrm{H}), 7.29(\mathrm{t}, 2 \mathrm{H}) ;{ }^{13} \mathrm{C} \mathrm{NMR}\left(\mathrm{CDCl}_{3}\right): 18.49,27.92$, $72.86,81.84,115.04,121.29129 .41,171.43 ;[\alpha]^{20}{ }_{\mathrm{D}}=-38\left(\mathrm{c} 0.8, \mathrm{CHCl}_{3}\right) ;$ ee $=90 \%(\mathrm{HPLC}$ conditions: Lux-Cellulose-3 column, heptane $/ \mathrm{i}-\mathrm{PrOH}: 95 / 5$, flow rate $=1 \mathrm{ml} / \mathrm{min}$, wavelength $=254 \mathrm{~nm}, t_{\mathrm{R}}=4.83 \mathrm{~min}$ for minor isomer, $t_{\mathrm{R}}=5.24 \mathrm{~min}$ for major isomer). $\operatorname{HRESIMS~}(\mathrm{m} / \mathrm{z})$ calcd for $\mathrm{C}_{13} \mathrm{H}_{18} \mathrm{O}_{3} \mathrm{Na}: 245.11536[\mathrm{M}+\mathrm{Na}]^{+}$, found: 245.1154 . 
(-)-t-Butyl-2-(p-fluorophenoxy)propionate 3k. Yield: 70\%; ${ }^{1} \mathrm{H}$ NMR $\left(\mathrm{CD}_{2} \mathrm{Cl}_{2}\right): \delta=1.46(\mathrm{~s}$, $9 \mathrm{H}), 1.58(\mathrm{~d}, 3 \mathrm{H}), 4.62(\mathrm{q}, 1 \mathrm{H}), 6.85-6.88(\mathrm{~m}, 2 \mathrm{H}), 6.96-7.0(\mathrm{~m}, 2 \mathrm{H}) ;{ }^{13} \mathrm{C} \mathrm{NMR}\left(\mathrm{CDCl}_{3}\right)$ : $18.49,27.69,73.59,81.7,115.56,115.79,116.13,116.61,157.2,171.00 ;[\alpha]^{20}{ }_{D}=-24.1(\mathrm{c} 0.6$, $\left.\mathrm{CHCl}_{3}\right)$; ee $=83 \%$ (HPLC conditions: Lux-Cellulose-3 column, heptane/i-PrOH : 95/5, flow rate $=1 \mathrm{ml} / \mathrm{min}$, wavelength $=254 \mathrm{~nm}, t_{\mathrm{R}}=5.81 \mathrm{~min}$ for minor isomer, $t_{\mathrm{R}}=6.14 \mathrm{~min}$ for major isomer). HRESIMS $(\mathrm{m} / \mathrm{z})$ calcd for $\mathrm{C}_{13} \mathrm{H}_{17} \mathrm{O}_{3} \mathrm{FNa}$ : $263.10539[\mathrm{M}+\mathrm{Na}]^{+}$, found: 263.1054 .

\section{References and notes}

1. Ye, T.; McKervey, M. A. Chem. Rev. 1994, 94, 1091-1160.

2. Miller, D. J.; Moody, C. J. Tetrahedron 1995, 51, 10811-10843.

3. Doyle, M. P.; McKervey, M. A.; Ye , T. Modern Catalytic Methods for Organic Synthesis with Diazo Compounds, Wiley: New York, 1998.

4. Gillingham, D.; Fei, N. Chem. Soc. Rev. 2013, 42, 4918-4931.

5. Ford, A.; Miel, H.; Ring, A.; Slattery, C. N.; Maguire, A. R.; McKervey, M. A. Chem. Rev. 2015, 115, 9981-10080.

6. Burtoloso, A. C. B.; Santiago, J. V.; Bernardim, B.; Talero, A. G. Curr. Org. Synth. 2015, 12, 650659.

7. Moody, C. J. Angew. Chem.; Int. Ed. Engl. 2007, 46, 9148-9150.

8. Zhang, Z.; Wang, J. Tetrahedron 2008, 64, 6577-6605.

9. Saito, H.; Iwai, R.; Uchiyama, T.; Miyake, M.; Miyairi, S. Chem. Pharm. Bull. 2010, 58, 872-874.

10. Zhu, S.-F.; Zhou, Q.-L. Acc. Chem. Res. 2012, 45, 1365-1377.

11. Zhu, S.-F.; Zhou, Q.-L. National Science Review 2014, 00, 1-24.

12. Perron, Y. G.; Minor, W. F.; Holdrege, C. T.; Gottstein, W. J.; Godfrey, J. C.; Crast, L. B.; Babel, R. B.; Cheney, L. C. J. Am. Chem. Soc. 1960, 82, 3934-3938.

13. Bettoni, G.; Loiodice, F.; Tortorella, V.; Conte-Camerino, D.; Mambrini, M.; Ferrannini, E.; Bryant, S. H. J. Med. Chem. 1987, 30, 1267-1270.

14. Chimichi, S.; Boccalini, M.; Cravotto, G.; Rosati, O. Tetrahedron Lett. 2006, 47, 2405-2408.

15. Aller, E.; Brown, D. S.; Cox, G. G.; Miller, D. J.; Moody, C. J. J. Org. Chem. 1995, 60, 4449-4460. 
16. Ferris, L. H., D.; Moody, C. J. Tetrahedron Lett. 1996, 37, 107.

17. Bulugahapitiya, P.; Landais, Y.; Parra-Rapado, L.; Planchenault, D.; Weber, V. J. Org. Chem. $1997,62,1630-1641$.

18. Maier, T. C.; Fu, G. C. J. Am. Chem. Soc. 2006, 128, 4594-4595.

19. Chen, C.; Zhu, S.-F.; Liu, B.; Wang, L.-X.; Zhou, Q.-L. J. Am. Chem. Soc. 2007, 129, 1261612617.

20. Zhu, S.-F.; Chen, C.; Cai, Y.; Zhou, Q.-L. Angew. Chem.; Int. Ed. Engl. 2008, 47, 932-934.

21. Zhu, S.-F.; Song, X.-G.; Li, Y.; Cai, Y.; Zhou, Q.-L. J. Am. Chem. Soc. 2010, 132, 16374-16376.

22. Zhu, S.-F.; Cai, Y.; Mao, H.-X.; Xie, J.-H.; Zhou, Q.-L. Nat. Chem. 2010, 2, 546-551.

23. Osako, T.; Panichakul, D.; Uozumi, Y. Org. Lett. 2012, 14, 194-197.

24. Liang, Y.; Zhou, H.; Yu, Z.-X. J. Am. Chem. Soc. 2009, 131, 17783-17785.

25. Pereira, A.; Champouret, Y.; Martín, C.; Álvarez, E.; Etienne, M.; Belderraín, T. R.; Pérez, P. J. Chem. Eur. J. 2015, 21, 9769-9775.

26. Atodiresei, I.; Schiffers, I.; Bolm, C. Tetrahedron: Asymmetry 2006, 17, 620-633.

27. Takacs, J. M.; Quincy, D. A.; Shay, W.; Jones, B. E.; Ross li, C. R. Tetrahedron: Asymmetry $1997,8,3079-3087$.

28. Le Maux, P.; Simonneaux, G. Tetrahedron 2015, 71, 9333-9338.

29. Galardon, E.; Le Maux, P.; Simonneaux, G. J. Chem. Soc., Perkin Trans. 1 1997, 2455-2456.

30. Galardon, E.; Le Maux, P.; Simonneaux, G. Tetrahedron 2000, 56, 615-621.

31. Srour, H. F.; Maux, P. L.; Chevance, S.; Carrié, D.; Yondre, N. L.; Simonneaux, G. J. Mol. Cat. A: Chem. 2015, 407, 194-203.

32. Bachmann, S.; Fielenbach, D.; Jorgensen, K. A. Org. Biomol. Chem. 2004, 2, 3044-3049.

33. Liu, B.; Zhu, S.-F.; Zhang, W.; Chen, C.; Zhou, Q.-L. J. Am. Chem. Soc. 2007, 129, 5834-5835.

34. Salomon, R. G.; Kochi, J. K. J. Am. Chem. Soc. 1973, 95, 3300-3310.

35. Fraile, J. M.; Mayoral, J. A.; Ravasio, N.; Roldán, M.; Sordelli, L.; Zaccheria, F. J. Catal. 2011, $281,273-278$.

36. Zhu, S.-F.; Xu, B.; Wang, G.-P.; Zhou, Q.-L. J. Am. Chem. Soc. 2012, 134, 436-442.

37. Austeri, M.; Rix, D.; Zeghida, W.; Lacour, J. Org. Lett. 2011, 13, 1394-1397.

38. Le Maux, P.; Dorcet, V.; Simonneaux, G. Tetrahedron 2013, 69, 8291-8298. 